\title{
Male proportion in offspring of military air pilots in Norway
}

\author{
Ågot Irgens ${ }^{1}$ and Lorentz M. Irgens ${ }^{2}$ \\ 1. Department of Occupational Medicine, Haukeland Hospital, Bergen, Norway \\ 2. Medical Birth Registry of Norway, University of Bergen, Norway
}

\begin{abstract}
Rumours of a reduced male proportion in offspring of fathers occupied as military air pilots were confirmed in two American studies in 1961 and 1987, but not in a German study in 1976. Data of the Medical Birth Registry of Norway were used to assess whether offspring of fathers occupied as military air pilots, had a deviant sex-ratio.

Method. The study was based on all births in Norway 1970-1993 for which linkage with population census data could be obtained (about 1.2 million). Fathers' occupation was derived from census data of 1970, 1980 and 1990 on job title and education. The reference population was the group that did not belong to the occupation under study.

Results. Men working as military air pilots had 65 infants. The male proportion was $36.9 \%$, the male proportion in the reference population was $51.4 \%$ with a relative risk 0.72 (95\% CI $0.57-0.92$ ).

Conclusion. Male proportion in offspring of men occupied as military air pilots was significantly reduced. However, the group is small and the result needs to be confirmed in other studies.
\end{abstract}

\section{NORSK SAMMENDRAG}

Rykter om redusert andel sønner av fedre ansatt som flyvere i forsvaret, ble støttet $\mathrm{i}$ to amerikansk studier fra 1961 og 1987, men ikke i en tysk studie fra 1976. Data fra Medisinsk fødselsregister ble brukt til å undersøke om fødte, etter 16. svangerskapsuke, med fedre som flyvere i forsvaret i Norge, hadde en skjev kjønnsratio.

Metode. Studien var basert på alle fødte i Norge 1970-1993 med tilgjengelig folketellings-informasjon (ca. 1,2 millioner). Kohorten av flyvere ble etablert ut fra opplysninger om yrke og utdannelse i folketellingene fra 1970, 1980 og 1990. Referansepopulasjonen var alle resterende barn.

Resultat. Flyvere i forsvaret var fedre til 65 barn. Andelen av gutter var 36,9\%, i referansepopulasjon var andelen $51,4 \%$ med en relativ risiko $0,72(95 \%$ CI 0,57-0,92).

Konklusjon. Andel sønner til mannlige flyvere i forsvaret var signifikant redusert. Gruppen er imidlertid liten og resultatet bør bekreftes av andre studier.

\section{INTRODUCTION}

Mechanisms causing a skewed sex-ratio at birth, i.e. an altered ratio between proportions of male and female births, are still far from clarified. A reduced male proportion might be caused by a reduced fertilising capacity or survival of male spermatocytes (1) or by an increased early abortion rate of male foetuses. These mechanisms might be influenced by occupational exposures.

In the early 1970's, a rumour was reported of a low male proportion in offspring of military air pilots in a Norwegian military base, possibly influenced by an American study published in 1961 (2). A study from the 1980's attributed a deviant sex-ratio in offspring of air pilots to exposure to G-forces (3). An Australian case report stated that pilots in high-performance aircrafts may be subject to incidental infertility (4).

The objective of the present study was to test the hypothesis that the male proportion in offspring of military air pilots was reduced. The analyses were based on data on all births above 16 weeks of gestation notified to the Medical Birth Registry of Norway and linked with population censuses derived occupational data.

\section{MATERIAL AND METHODS}

By means of the national personal identification number, all records of the Medical Birth Registry of Norway 1970-1993 were linked with general population census records. The father's job title and edu- 
cation were derived from the censuses of 1970,1980 or 1990. The census data prior to the birth were used. Linkage was obtained for about 1.2 million records.

The occupational coding system used in the censuses (5) did not specify military air pilots per se. Therefore, we selected men occupied in the military services qualified as air pilots. In this group, also helicopter pilots were included.

Altogether, 65 children had fathers occupied as military air pilots 1970-1993. All offspring of fathers who did not have the occupation under study, were used as a reference population. As a comparison, all 869 infants of commercial air pilots were studied as well.
Relative risks, defined as the ratio between the male and the female proportions, i.e. the sex ratio, were calculated directly by the statistical programme BMDP 4F Release: 7.1 (SUN/UNIX) (6). Since no potential confounders to gender are known so far, no adjustments were performed.

\section{RESULTS}

Offspring of men working as air pilots in the military services, altogether 65 infants, had a reduced male proportion, with a significantly reduced relative risk (table 1). The exposed group was small. Offspring of commercial air pilots had no deviant male proportion.

Table 1. Male proportions with relative risks and $95 \%$ confidence intervals in offspring of fathers occupied as military air pilots, as commercial air pilots, and in the reference population, all births in Norway 1970-93.

\begin{tabular}{lrccc}
\hline & $\begin{array}{c}\text { number of } \\
\text { offspring }\end{array}$ & \% males & RR & 95\% CI \\
\hline unexposed & 1180374 & 51,42 & 1 & Referent \\
military air pilots & 65 & 36,92 & 0,72 & $0,57-0,92$ \\
commercial air pilots & 869 & 52,6 & 1,02 & $0,96-1,09$ \\
\hline
\end{tabular}

\section{DISCUSSION}

A significantly reduced male proportion was observed in the offspring of male military pilots, but not in the offspring of commercial air pilots.

In the present study, no specific data on exposure were at hand, nor data on flight activity (altitude, duration, the plane) prior to the conception. Furthermore, misclassification even of occupation based on job titles (work in military services) and education (as air pilot) might occur. These data are reported from the years 1970, 1980 and 1990. We have systematically used the data prior to the birth. Since occupation in the period between two censuses is unknown, the degree of misclassification will increase as time of birth moves from the year of the census. The misclassification in this study might possibly involve a shift from military to commercial occupation. However, especially in the late 1980's, the unemployment rate for pilots in the private sector increased, reducing the shift from the military to the private companies. Any occupational misclassification would attenuate the true relative risk.

Confounding factors relevant to the sex-ratio of the offspring have so far not been established. Furthermore, biological mechanisms influencing the sex-ratio are not known.

Rumours of a reduced male proportion in the offspring of fathers occupied as military air pilots were con- firmed in an American study in 1961 (2). A German study attributed sex-ratio in the offspring of air pilots to stress (7). In this study, jet pilots with 1000 flying hours or less had more sons, while for pilots with more than 1000 hours, the sex-ratio shifted to more daughters. Some studies have evaluated the effects of G-powers on the body and the use of protection suits in the aircraft (8). An American study (3) has attributed a reduced male proportion in offspring to father's exposure to G-powers. Since commercial air pilots are expected to be less exposed to G-powers than fighter pilots, the results of that study are compatible with the findings in our study. However, several additional exposure differences might exist between military and commercial pilots: exposure to electromagnetic fields, radiofrequency fields caused by radar and radio transmitters, noise, vibration, cosmic radiation and oxygen-breathing which might influence the offspring's sex-ratio. A letter to the Lancet in 1982 (9) reported that offspring of 58 licensed divers had a reduced male proportion. Divers, as well as air pilots, are exposed to stress and oxygen-breathing.

Also other occupations might be associated with a skewed sex-ratio. A significantly higher proportion of girls has been found in offspring of carbon setters and a subgroup of aluminium workers (10), and a tendency of reduced male proportion in offspring of various smelter workers has been reported in Norway (11). 
Likewise, a Danish study reported a reduced sex-ratio in offspring of female physiotherapists working with short wave treatment (12). In these studies, exposure to electromagnetic fields might occur. However, a reduced sex-ratio has also been observed in offspring of men working as 1,2-dibromo-3-chloropropane (DBCP) applicators $(13,14)$ and drivers $(15)$.

Finally, it has been pointed out that a skewed sexratio in offspring has been found in some occupations, possibly explained by a high level of gonadotropin or a low level of testosteron in men in the occupations involved (16). For women, the same author (1) hypothesised that a high level of oestrogen is favouring males and a high level of progesterone females. Studies have investigated the timing of sexual intercourse in relation to ovulation and the sex of the baby, but the results have been contradictory $(17,18)$.

\section{CONCLUSION}

This study supports previous findings of a reduced sex-ratio in offspring of military air pilots. However, based on small numbers the findings need to be confirmed in further studies which should focus on the effects on sex-ratio of the various occupational exposures of military air pilots.

In large parts of the world, sex distribution at birth is an outcome of minor social implication. However, we cannot rule out that a skewed sex ratio can be an indicator of important biological effects, and ought to be followed carefully.

\section{ACKNOWLEDGEMENTS}

This study was supported by a grant from Statoil Norway, Fund for Occupational Medical Research.

\section{REFERENCES}

1. James WH. The hypothesised hormone control of mammalian sex ratio at birth - a second update. $J$ Theor Biol 1992; 155: 121-8.

2. Snyder RG. The sex ratio of offspring of pilots of high performance military aircraft. Human Biol 1961; 33: $1-10$.

3. Little BB, Rigsby CH, Little LR. Pilot and astronaut offspring: Effects on human sex ratio. Aviat Space Environ Med 1987; 58: 707-9.

4. Jequier AM. High-performance aircraft - a possible cause of male infertility. Brit J Urol 1996; 77: 918-31.

5. Nordic Occupational Classification. City of Oslo (copies of the occupational coding system can be ordered from Statistics Norway, Oslo) Norwegian title: Nordisk Yrkesklassifisering, 1965 (NYK).

6. Dickson WJ. BMDP Statistical Software Manual. University of California Press, 1990.

7. Goerres HP, Gebert K. Sex ratio in offspring of pilots: A contribution to stress research. Aviat Space Environ Med 1976; 47: 889-92.

8. Krock LP, Balldin UI, Harms-Rinfdahl K, Singstad BA, Linder J, Siegborn J. Influence of a reduced G-suit pressure schedule on G-duration tolerance using enhanced G-protection ensembles. Aviat Space Environ Med 1997; 68: 403-9.

9. Lyster WR. Altered sex ratio in children of divers. Lancet 1982; ii: 152.

10. Milham S. Unusual sex ratio of births to carbon setter fathers. Am J Ind Med 1993; 23: 829-31.

11. Irgens $\AA$, Krüger K, Skorve AH, Irgens LM. Male proportion in offspring of parents exposed to strong static and extremely low-frequency electromagnetic fields in Norway. Am J Ind Med 1997; 32: 557-61.

12. Jensen AI. Graviditetsforløb og utsettelse for kortbølgestråling. Arbejdsmiljøfondet, Copenhagen, 1991, ISBN 87-7359-514-4.

13. Potashnik G, Yana-Inbar I. Dibromocloropropane (DPCP): An 8-year evaluation of testicular function and reproductive performance. Fertil Steril 1987; 47: 317-23.

14. James WH. Offspring sex ratio: An indicator of reproductive hazards associated with pesticides. Occup Environ Med 1995; 52 (6): 429-30.

15. Dickinson H, Parker L. Do alcohol and lead change the sex ratio? J Theor Biol 1994; 169: 313.

16. James WH. Occupations associated with low offspring sex ratios. Am J Ind Med 1994; 25: 607-8.

17. James WH. Cycle day of insemination, sex ratio of offspring and duration of gestation. Ann Hum Biol 1994; 21 (3): 263-6.

18. Wilcox AJ, Weinberg CR, Baird DD. Timing of sexual intercourse in relation to ovulation. Effects on the probability of conception, survival of the pregnancy, and sex of the baby. $N$ Engl J Med 1995; 333: 1517-21. 